2. Maslov, V. I. (2007). Scientific basics and functions of the management process of secondary educational institutions. Ternopil: Aston, 7-8.

3. Ninuk, I. (2004). Features of the analysis of professionalism of civil servants. Collection of scientific papers NADU, 2, 225-234.

4. Vasilenko, V. A., Shmatko, V. G.; Vasilenko, V. A. (Ed.) (2009). Innovation management. Kyiv: Center of educational literature, 440.

5. Vashchenko, L. M. (2012). Conceptual bases of organization of educational process for professional development of pedagogical, scientific-pedagogical and managing staff of education in the conditions of innovative development of institutions of postgraduate teacher education. Innovative model of organization of educational process in institutes of postgraduate pedagogical education. Kyiv: Pedagogical thought, 63-68.

6. Voznyuk, S. V. (2007). Marketing of educational services. Lutsk: Volinska book, 64.

7. El'nikova, G. V. (1999). Scientific bases of development of the Department of General secondary education in the region. Kyiv: of DAKKO, 303.

8. Karamushka, L. (1997). Psychological foundations of governance in secondary education. Kyiv: Academy of pedagogical Sciences of Ukraine, Institute of psychology, 179.

9. Potashnik, M. M. (1997). Management of modern school (questions and answers). Moscow: New HQ., 350.

10. Danilenko, L. I. (2007). Management of innovations in education. Kyiv: SHK. world, 120.
11. Averintsev, S. S., Arab-Ogly, E. A., Ilichev, L. F. et. al (Eds.) (1989). Philosophical encyclopedic dictionary. Moscow: Owls. Encyclopedia, 815.

12. Novak, V. A. (2001). fundamentals of the theory of management. Kyiv: NAU, 236.

13. Nazarenko, V. S., Nazarenko, L. M., Odainik, S. F. (2015). Professional success of the teacher as a sociopedagogical problem. Chep. 1. Kharkov, 96.

14. Mudrak, I. V. (2007). Modern tendencies of development of Ukrainian higher education in the global educational space. Kn. 1. Ukrainian education in the world greenprotective. Kyiv: Ukrainian Agency of press and information "Rada", 362-363.

15. Karpov, A. (2005). Century Psychology of management. Moscow: Gardariki, 584.

16. Doronina, M. S., Naumych, K. G. (2006). Organizational culture. Kharkov: Publishing House. GNU, 80.

17. Chernovol-Tkachenko, G. I. (2014). Equipment management activities. Kharkiv: Type. group "Osnova", 272.

18. Valinchuk, Yu. V. (2007). Higher education future human. Kn. 1.Ukrainian education in the world greenprotective. Kyiv: Ukrainian Agency of press and information "Rada", 88-89.

19. Dmitrenko, G. A. (1996). Strategic management: trust management-based education qualimetrics approach. Kyiv: SMN, 140.

20. Zaichenko, A. I. (2001). Systematic work with senior staff - enhance their professional competence. Quality Management professional education. Donetsk, 333-335.

21. Ryabov, S. V. (2011). Marketing research in the management of the school. Theory and methodology of education management, 5. Availavble at: http://tme.umo.edu.ua/

Назаренко Людмила Миколаӥвна, кандидат педагогічних наук, доцент, кафедра менеджменту освіти, Херсонська академія неперервної освіти, вул. Покришева, 41, м. Херсон, Україна, 73034 E-mail: nazarenko-1@bigmir.net

\title{
УДК 37.013-053.6:007
}

\section{ОСОБЛИВОСТІ ФОРМУВАННЯ ІНФОРМАЦЙНОЇ КУЛЬТУРИ МОЛОДШИХ ПІДЛІТКІВ}

\section{(C) Л. С. Тріфаніна, Р. Х. Вайнола}

Досліджено особливості формування інформачійної культури молодиих підлітків у навчальновиховному прочесі загальноосвітнього навчального закладу. Визначено анатомо-фізіологічні особливості молодшого підліткового віку, щзо обумовлюють формування інформаційної культури. Виокремлено психологічні особливості в когнітивній (пізнавальній), емоційно-вольовій та мотиваційній сферах розвитку молодшого підлітка, які обумовлюють формування інформаційної культури в даному віковому періоді Ключові слова: інформачійна культура, молодчий підлітковий вік, анатомо-фізіологічні особливості, психологічні особливості

Statement of the problem: The process of formation on information culture of the young teenagers is very complicated and many-sided. It needs for more detailed and thorough consideration of scientists because it is no unified complex approach to this problematic.

Aim: the theoretical grounding of the features of formation of information culture in young teenagers.

Main results of research: the features connected with transformation of organism of the young teenagers that condition the formation of information culture are: the heightened activity and significant raise of energy, specific manifestation of the mental activity of young teenager, heightened emotionality, heightened fatiguability.

The cognitive sphere of the young teenagers also changes; this process is characterized with the certain features that condition the formation of information culture. In this period the perception, attention, imagination, thinking and memory are changed. The main feature of imagination is the clearly expressed fantasy. The special features of perception are: planned character, consistency and superficiality. The special features of attention are: increase of volume, concentration and stability. The special features of thinking are the increase of diapason and flexibility. The special feature of memory is the increase of amount of memorization of abstract material. 
The special features of emotional-willing sphere are: ability to the willing activity; continuousness and stability offeelings.

The special feature of motivational sphere is purposefulness, activity and the deepness of interests.

Situation of social development at the young teenager period has the important special features: communication with people of same age, striving for independence, "feeling of being adult", the main kind of activity in this age stays the study.

The formation of information culture of the young teenagers in conditions of the general educational institution has several features: obtaining of the primary skills of scientific activity, intellectual activity, intellectual selfaffirmation in studying, inclination to experiments, generation of worldview of the young teenager, formation of esthetic feelings of the young teenager.

Scientific novelty of the results of research. The special features of formation of information culture of the young teenagers at the educational process were considered.

Conclusions and concrete suggestions. So, taking into account the aforesaid features of the young teenagers we can attain the effective results in the formation of information culture.

Then, it is necessary to elaborate and introduce the new pedagogical conditions, content and methods of their realization

Keywords: information culture, young teenager, anatomic-physiologic features, psychological features

\section{1. Вступ}

3 розумінням неповторної ролі інформації в загальній картині світу, з формуванням інформаційного підходу до пізнання дійсності виникла потреба у формуванні інформаційної культури як культури нового типу. Формування інформаційної культури починається в родині, до нього долучаються бібліотека, 3МІ, загальноосвітній навчальній заклад, ВУЗ, потім воно продовжується на протязі усього активного життя.

Сьогодні підготовка молодого покоління, особливо молодших підлітків, до життя в глобальному інформаційному суспільстві майбутнього передбачає не тільки навчання навичкам традиційної читацької та інформаційної грамотності, але й новим ії видам, а саме комп'ютерної та медіа-грамотності, включаючи виховання культури особистості в широкому іiі розумінні. Інформаційна культура для сучасного молодшого підлітка $є$ необхідною умовою його успішної соціальної адаптації та результативної діяльності в будь-якій сфері. Особлива унікальна роль у формуванні інформаційної культури молодших підлітків відводиться загальноосвітнім навчальним закладам, які мають змогу створити інформаційне навчальне середовище.

Зважаючи, на необхідність формування інформаційної культури у молодших підлітків, актуальним завданням стає розгляд особливостей даного процесу.

\section{проблеми \\ 2. Аналіз літературних даних та постановка}

Вперше у вітчизняний науковий оббіг термін «інформаційна культура» було введено Г. Г. Воробйовим [1]. У подальшому, визначенням поняття «інформаційна культура» займалися такі вчені як: С. Г. Антонова [2], Н. Б. Зінов'єва [3], Ю. С. Зубов [4], Н. І. Гендіна [5], О. А. Гречихін [6], А. П. Сршов [7], Є. А. Медведєва [8], Е. П. Семенюк [9], А. П. Суханов [10], І. Г. Хангельдієва [11].

Формування інформаційної культури особистості висвітлено в працях таких вітчизняних науковців, як Л. С. Винарик [12], Н. Г. Джинчарадзе [13], А. Н. Дулатова [14], А. М. Коломієць [15], О. В. Матвієнко [16], О. В. Пруднікова [17], та ін.
Проблеми новоутворень підліткового, зокрема молодшого підліткового віку знайшли відображення в працях з вікової психології таких авторів, як: Г. С. Абрамова [18], П. П. Блонський [19], Л. П. Василенко [20], Л. С. Виготський [21], М. М. Забродський [22], М. Кле [23], В. П. Кутішенко[24], М. В. Савчин [20], М. І. Талько [25], Л. Г. Терлецька [26], Д. І. Фельдштейн [27], Я. С. Фруктова [28].

Особливості соціально-виховної діяльності 3 підлітками в загальноосвітніх навчальних закладів розглядали такі вчені як: І. В. Андрощук [29], А. Б. Леонова [30], 3. М.Онишків [31].

Проте визначення особливостей формування інформаційної культури молодших підлітків не стало самостійним предметом дослідження в теорії та практиці сучасної педагогічної науки.

Сьогодні, сукупність інформаційних потоків навколо підростаючого покоління настільки велика, різноманітна і розгалужена, що вимагає від нього не тільки знання законів інформаційного середовища й уміння орієнтуватися в них, а й безпосередньої участі у його формуванні та перетворенні, сприянні інформаційним контактам. Все це обумовило появу концепції формування інформаційної культури підростаючого покоління. В теорії та практиці сучасної педагогічної науки й досі немає одностайної думки щодо процесу формування інформаційної культури особистості, а отже і конкретних шляхів вирішення даної проблеми. Молодший підлітковий вік залишається самим складним періодом життя, який потребує більшої уваги з боку науковців. Тому, виникає необхідність подальшого аналізу особливостей формування інформаційної культури у молодшому підлітковому віці.

\section{3. Мета статті}

Здійснити теоретичне обгрунтування особливостей формування інформаційної культури молодших підлітків.

4. Особливості молодших підлітків, що обумовлюють формування інформаційної культури

На думку Я. Фруктової, молодший підлітковий вік (від 10-11 до 13 років) - це вузлова межа між ета- 
пами онтогенезу («Я» і суспільство), який пов’язаний 3 актуалізацією діяльності із засвоєнням моральноетичних норм людських відносин, прагненням отримати визнання оточенням, зайняти у суспільстві відповідну нішу[28].

3 метою виконання нашого завдання, розглянемо анатомо-фізіологічні особливості, які притаманні цьому віку та обумовлюють формування інформаційної культури.

Для молодшого підліткового віку характерні такі особливості поведінки, як підвищена активність та значне зростання енергії, оскільки відбувається перебудова всього організму дитини, зумовлена насамперед статевим дозріванням. Активізація діяльності статевих та інших залоз внутрішньої секреції спричинює інтенсивний фізичний, фізіологічний та розумовий розвиток. У цьому віці прискорюється зріст організму, досягаючи для хлопчиків найвищих показників у 13 років і продовжуючись до 15-17 років. У дівчаток цей процес розпочинається і закінчується на два роки раніше. Зміцнюється м'язовоскелетна система, зростає фізична сила.

Тому, на нашу думку, ці зміни, які обумовлюють дану особливість, сприяють швидкому залученню молодших підлітків до будь-якої діяльності, зокрема інформаційної, що сприяють формуванню інформаційної культури.

Наступною особливістю, на яку ми звернули нашу увагу, є особливість прояву розумової активності молодшого підлітка. Це зумовлено тим, що вага головного мозку молодшого підлітка наближається до показників дорослої людини. Розвиваються ділянки мозку (лобні, частково скроневі і тім'яні), відбувається внутрішньоклітинне вдосконалення кори головного мозку, збагачуються асоціаційні зв'язки між різними ділянками мозку. Інтенсивно розвивається друга сигнальна система. Досконалими стають гальмівні процеси. Зростає контрольна діяльність кори великих півкуль стосовно підкірки тощо [22].

Отже, враховуючи розумову активність, як характерну особливість, ми можемо зазначити, що молодші підлітки готові та здатні до різних видів навчання, як в практичному (вміння, навички), так i теоретичному (вміння думати, міркувати, користуватися поняттями) планах, які є необхідними щодо формування інформаційної культури.

Ще однією анатомо-фізіологічною особливістю $є$ підвищена емоційність молодших підлітків, як одна із значимих особливостей, зумовлена неврівноваженістю процесів збудження і гальмування, 3 явною перевагою перших, їх підвищена збудливість пояснює схильність до афектів - різких виявів радості, гніву, невдоволення та ін. Річ у тім, що на цьому етапі виникає невеликий, «фізіологічний» гіпертиреоз» - підвищення функцій щитовидної залози. Впливаючи на зріст тіла й обмін речовин, гормон щитовидної залози збудливо діє на ЦНС (центральна нервова система). Звідси і підвищена дратівливість, а також і емоційна лабільність молодших підлітків [33].

Тому, ми можемо стверджувати, що підвищена емоційність молодшого підлітка сприяє швидкому «загорянню», активному емоційному піднесенню в отри- манні щось нового, корисного, тим самим створюючи передумови для формування інформаційної культури.

Яскраво вираженою особливістю молодших підлітків є підвищена стомлюваність. Вона обумовлена прискореним зростом організму, який потребує значних зусиль. Значно знижується витривалість, тому для них є характерним складність виконання монотонних робіт. Вони потребують зміни виду діяльності через кожні 8-10 хвилин. Якщо підлітки старшого віку потребують в першу чергу правильної своєчасної організації їхньої діяльності, а порушення ними дисципліни частіше пов'язане $з$ тим, що їх надмірна енергія не знаходить правильного виходу, то молодші підлітки потребують правильної організації обсягу їхньої діяльності, пом'якшеного режиму [30].

Зважаючи на дану особливість, як підвищена стомлюваність, педагоги повинні враховувати час виконання передбачуваних робіт для ефективного формування інформаційної культури.

Отже, нами було визначено анатомо-фізіологічні особливості формування інформаційної культури молодших підлітків, а саме: підвищена активність та значне зростання енергії, особливість прояву розумової активності молодшого підлітка, підвищена емоційність, підвищена стомлюваність.

Наступною групою ми вважали, за доцільне розкрити психологічні особливості в когнітивній, емоційно-вольовій та мотиваційній сферах розвитку молодшого підлітка, які обумовлюють формування інформаційної культури в даному віковому періоді.

У молодшому підлітковому віці активно відбувається розвиток когнітивної (пізнавальної) сфери. У цей період змінюється сприймання, увага, уява, мислення та пам'ять.

Основною особливістю уяви в молодшому підлітковому віці $є$ наявність яскраво вираженої фанта3іï, яка розподіляється на суб'єктивну та об'єктивну. Суб'єктивна фантазія супроводжується настроєм, емоціями, почуттями, що переповнюють молодшого підлітка та надає особистого задоволення. Об'єктивна фантазія являє собою необхідне створення в практичній діяльності будь-якого нового образу чи нової побудови, ідеї [21].

Сприймання молодшого підлітка ускладнюється та інтенсивно формується. До його особливостей належить планомірність, послідовність та поверховість, так як воно стає більш активним, спостережливим. Саморегуляція сприймання у молодшого підлітка ще недосконала, оскільки він нерідко обмежується сприйманням якоїсь однієї сторони об'єкта. Це спотворює сприймання, або ж робить його поверховим, акцентуючи на те, що є найбільш яскравим, цікавим, вражаючим [33].

Розвивається післядовільна увага молодшого підлітка. Характерними особливостями якої $є$ зростання обсягу, концентрація і стійкість. Молодший підліток здатний тривалий час утримувати увагу на певному об'єкті. Виробляється здатність зосереджуватися на змісті будь-якої діяльності і відволікатись від сторонніх стимулів. Саме в молодшому підлітковому віці розвивається уміння тривалий час утримувати увагу на абстрактному, логічно-організованому 
матеріалі. Молодший підліток може змусити себе бути уважним, навіть при виконанні нецікавих завдань. Одночасно спостерігається відволікання i зниження уваги через одноманітність завдань.

У цьому віці зростають можливості зосереджувати увагу на об'єктах, що задані наочно, уявно, мислено. Вдосконалюється вміння розподіляти та перемикати увагу. Характерним для молодшого підлітка є прагнення виховувати в собі здатність бути уважним, переборювати слабкі сторони своєї уваги. Увага стає контрольованішою, зростають елементи самоконтролю й саморегуляції, що $є$ позитивною рисою [24].

У молодшому підлітковому віці відбуваються важливі процеси, пов'язані з перебудовою пам'яті. Особливістю якої $\epsilon$ збільшення кількості запам'ятовування абстрактного матеріалу, оскільки відбувається поступовий перехід від конкретнологічної до абстрактно-логічної пам'яті. В цей період все більшу роль відіграє опосередковане запам'ятовування через слово, підвищується роль другої сигнальної системи. Розвивається довільна та опосередкована пам'ять. Розвиток пам'яті відбувається у напрямі ії інтелектуалізації [20].

Особливостями мислення даного вікового періоду є збільшення діапазону і гнучкість. Внаслідок активного розвитку мислення, його зміст стає багатшим і складнішим. Молодші підлітки тепер можуть розглядати ситуації, які суперечать фактам. Вони можуть змінити раніше складений план розв'язку задачі, якщо він не відповідає умовам, які виділились у ході розв'язку [19].

Тому, на нашу думку, особливості розвитку пізнавальних процесів значно полегшують, а водночас i прискорюють процес формування інформаційної культури, оскільки є сензетивними і відкритими для отримання знань, умінь та навичок і надають можливості використовувати різноманітні форми та методи для досягнення поставлених завдань.

У цьому періоді зазнає значних змін емоційновольова сфера. Особливістю якої виступає спроможність на вольову діяльність, оскільки помітного розвитку набувають вольові якості - наполегливість, впертість у досягненні мети, вміння долати перешкоди і труднощі тощо.

Молодші підлітки, на відміну від молодших школярів, спроможні не тільки на окремі вольові дії, а й на вольову діяльність. Вони вже взмозі самі поставити перед собою мету та спланувати ії досягнення. Недостатність волі полягає передусім у тому, що, проявляючи величезну наполегливість в одному виді діяльності, молодші підлітки можуть не виявляти ії в інших видах. Виготський Л. С. зазначав, що у молодших підлітків найчастіше спостерігається не слабкість волі, а слабкість цілей, коли молодшим підліткам просто немає задля чого долати різні перепони, а також власні лінощі.

Таким чином, спроможність на вольову діяльність дозволяє педагогам ставити перед молодшими підлітками цілі та завдання, які вимагатимуть більших зусиль і часу, що надає можливість для формування інформаційної культури.
У молодшому підлітковому віці відбувається подальший розвиток почуттів як узагальнених, так i відносно стійких переживань (інтелектуальних, моральних, естетичних). Особливостями, яких є тривалість і стійкість, що зумовлюють посилення їх впливу на всі сторони життя молодших підлітків. Поступово відбувається перехід від ситуаційного переживання краси явищ, природи, музичних і літературних творів, творів живопису до стійких естетичних почуттів, які $\epsilon$ наслідком систематичного виховання. Помітні зміни в інтелектуальних почуттях виражаються в пізнавальній діяльності, в розумінні нового, в розвитку пізнавальних потреб та інтересів.

Розвиток моральних почуттів набуває суттєвих змін саме у молодшому підлітковому віці, завдяки чому засвоювані ними норми поведінки можуть ставати ефективним поштовхом до дій. Молодші підлітки, на відміну від молодших школярів, здатні значною мірою оперувати узагальненими моральними категоріями, що зокрема дозволяє їм наблизитись до оцінки людини як особистості, враховуючи не тільки іiі зовнішню поведінку, а й суть її вчинків [20].

Отже, визначені нами особливості почуттів, такі як тривалість і стійкість, сприяють формуванню інформаційної культури в даному віковому періоді, оскільки яскравими характеристиками молодшого підлітка $є$ схильність до сприйняття та розуміння інформаційного матеріалу.

Мотиваційна сфера молодших підлітків характеризується розвитком інтересів. Інтереси молодшого підлітка, порівняно з молодшим школярами набувають більшої цілеспрямованості, активності та глибини, що являється їх особливостями [22].

Їх інтереси часто переростають в захоплення. Захоплення мають нестійкий характер і часто змінюється, але інколи вони стають надзвичайним захопленням. Деякі з захоплень сприяють розвитку особистості молодших підлітків, оскільки задовольняють їх потребу у пізнанні, сприяють формуванню корисних звичок [20].

Тому, особливості інтересів, такі як цілеспрямованість, активність та глибина, надають педагогам можливість спрямувати молодших підлітків на формування інформаційної культури.

Соціальна ситуація розвитку в молодший підлітковий період має принципові відмінності від ситуацій розвитку в дитинстві та налічує важливі для нашого дослідження особливості.

В. П. Кутішенко наголошує, що в цьому віці інакше розставляються акценти між сім'єю, однолітками і школою. Головне місце серед мотивів позитивного ставлення до школи займає мотив спілкування 3 однолітками, що $є$ значущою особливістю, оскільки у спілкуванні із однолітками формується самосвідомість молодшого підлітка, його самооцінка й рівень вимог до себе та до інших. Головним змістом його особистісного спілкування стає інший підліток, так формується спільний погляд на життя, відносини між людьми і погляд на майбутнє, а відтак - особистісний сенс життя [24].

Спілкування 3 однолітками є важливим каналом інформації для молодших підлітків. Специфіч- 
ним видом міжособистісних відносин, у процесі яких вони здобувають навички соціальної взаємодії, формуються уміння підпорядковуватися колективній дисципліні, виробляються комунікативні навички [24].

Отже, ми можемо стверджувати, що процес спілкування з однолітками, сприяє створенню сприятливого підгрунтя для формування інформаційної культури молодшого підлітка.

Надаючи характеристику особистісним якостям молодших підлітків, зауважимо, що набуває яскравих проявів така риса, як прагнення до самостійності, що являє собою своєрідну особливість соціальної ситуації розвитку. Підлітки протестують проти дріб'язкової опіки, контролю, недовіри. Прагнуть діяти, чинити і виглядати як дорослий. Хочуть мати його права та його можливості. Потреба в самостійності і незалежності реалізується у бажанні самостійно діяти, у здатності приймати рішення і захищати власні погляди, в умінні без прямого керівництва, самостійно досягати поставленої мети, поводитись під впливом власних спонукань[20].

Розглянута нами як провідна для молодших підлітків риса самостійність стає особливістю, що характерна для цьому періоду, надає змоги педагогам використовувати самостійні завдання, доручення, самостійне опрацювання в різноманітних видах діяльності, що сприяє формуванню інформаційної культури молодшого підлітка.

Цей період також характеризується розвитком «почуття дорослості», як однією із особливостей, яка приймає участь у процесі становлення готовності дитини до життя в суспільстві дорослих як повноцінного і рівноправного члена. Цей процес передбачає розвиток не тільки об'єктивної, але й суб'єктивної готовності, яка необхідна для засвоєння суспільних вимог до діяльності, стосунків і поведінки дорослих [23].

Тому, зважаючи на особливість «почуття дорослі», ми можемо стверджувати, що вони здатні до паритетних взаємин, які сприятимуть процесу формування інформаційної культури.

Характеризуючи особливості молодшого підліткового віку, які створюють передумови для формування інформаційної культури, ми не можемо не зазначити те, що основним видом діяльності в цей період залишається навчання. Саме початок підліткового віку є сензитивним періодом для переходу в навчальній діяльності на новий, вищий рівень, коли для молодшого підлітка розкривається зміст навчальної діяльності як діяльності із самоосвіти й самовдосконалення. Перехід від молодшого шкільного віку до молодшого підліткового - перехід до нової, високої форми навчальної діяльності і нового ставлення до навчання, що набуває в цей період особистісного змісту [25].

У молодшого підлітка під час навчання 3'являються труднощі й суперечності. Успішність у навчанні пов'язана 3 усвідомленням дитиною важливості отримання знань, а також залежить і від іiї зацікавленості шкільними навчальними предметами.

Для нашого дослідження важливим є те, що разом із зміщенням інформаційних інтересів школяра від навчальної до пізнавальної діяльності зазнає від- повідних змін і структура його інфопотреби 3'являється свідомо обрана мета. Поява нової гармонії проявляється в усвідомленні себе в системі соціальних відносин, у системі, взаємозв'язків людей у суспільстві, в системі комунікації.

3 самого народження особа, коли починає розвиватися, отримує різноманітну інформацію про довкілля. У молодшому підлітковому віці особистість зростає у світі різних думок, суджень, уявлень інших людей стосовно того, якою вона $є$ і якою хочуть іiі бачити інші (батьки, родичі, друзі, учителі, знайомі, телебачення, реклама, газети тощо). У процесі взаємодії з іншими людьми молодший підліток оцінюється ними, що впливає на формування власних поглядів, на своє місце в суспільстві, визнання особистісних якостей, ставлення до успіхів і невдач, критичність, особливості стосунків 3 оточуючими [26].

Основна суспільна вимога, яка висувається до молодших підлітків у контексті сучасної культури, оволодіти певною сумою знань, вмінь та навичок, необхідних для входження в життя суспільства. Ця вимога, поєднуючись із загальною культурною традицією ставлення до освіти, робить проблему уміння і навчальних досягнень дуже важливою у молодшому підлітковому віці [22].

Отже, ми можемо зробити висновок, що розвиток молодшого підлітка, його соціалізація в інформаційному суспільстві потребує відповідної стратегії виховання, впливу з боку педагогів, цілеспрямованої діяльності $з$ формування системи специфічних якостей молодших підлітків, необхідних в умовах інформатизації.

\section{5. Особливості формування інформаційної культури молодших підлітків у навчально- виховному процесі}

Визначення особливостей молодшого підліткового віку, надало нам можливість далі виокремити особливості формування інформаційної культури молодших підлітків в умовах загальноосвітнього навчального закладу.

Однією 3 значущих особливостей формування інформаційної культури молодших підлітків в у мовах загальноосвітнього навчального закладу є отримання первинних навичок дослідницької діяльності.

Дослідницька діяльність складається 3 вміння працювати $з$ текстом: конспектування текстів, складання планів прочитаних текстів, складання тезисів, вибірки уривків з тексту (виписки, цитати), вміння виділяти головне. У процесі читання активізується формування цілісної особистості учня. В епоху комп'ютерних засобів, накопичення, зберігання, пошуку, передачі інформації читання почало втрачати свої пріоритети у більшості учнів. Читання є невід'ємною частиною інформаційного середовища. Текст, читання були і залишаться головними інструментами культури в будь-якому суспільстві, 3 використанням будь-яких, самих тонких інформаційних технологій. Яким би не був матеріальний носій, 3 текстом на ньому, він потребує процесу читання. Без читання не можливо володіти новітніми електронни- 
ми засобами інформації. На особистісному рівні як творчий процес читання активно формує у молодших підлітків інтелект, який є основою розвитку духовності особистості [14].

На нашу думку, така особливість як, отримання первинних навичок дослідницької діяльності в молодшому підлітковому віці сприяє формуванню інформаційної культури, оскільки полегшує процес закладання в них навичок вміння чітко, розбірливо, лаконічно, дотримуючись усіх правил побудови речень, надавати письмово отриману інформацію іншим членам суспільства і знаходити в різних джерелах інформацію для особистісних потреб.

Не менш значущою особливістю формування інформаційної культури молодших підлітків в умовах загальноосвітнього навчального закладу є інтелектуальна активність, яка стимулюється природною допитливістю. Вона полягає в прагненні до пошуку і набуття знань, до формування корисних умінь та навичок. Молодші підлітки знаходять заняття і книги, які відповідають їх інтересам та здатні надати інтелектуальне задоволення. В цьому віці переважає безпосередній інтерес до нових фактів та явищ, пов'язаних з інформацією, яку учні отримують на уроці [18].

Отже, інтелектуальна активність, як особливість, що притаманна цьому віку, дозволяє педагогам формувати інформаційну культуру, оскільки сприяє активному залученню до пошуків нових, корисних знань.

Характерною особливістю формування інформаційної культури молодшого підліткового віку в умовах загальноосвітнього навчального закладу $\epsilon$ схильність до експериментування, яка виявляється, зокрема в небажанні все приймати на віру. Вони виявляють широкі пізнавальні інтереси, які пов'язані 3 прагненням все самостійно перевірити, особисто впевнитись в істинності.

Тому, враховуючи таку особливість, як схильність до експериментування, педагоги можуть легко вмотивувати молодших підлітків до необхідності формування інформаційної культури.

Іншою особливістю у формуванні інформаційної культури молодшого підлітка в умовах загальноосвітнього навчального закладу є інтелектуальне самоствердження в навчанні. Воно полягає в бажанні розвинути, продемонструвати оточенню свої здібності, отримати від нього оцінки, у зв'язку з цим молодші підлітки прагнуть розв'язувати найбільш складні завдання, нерідко проявляють не тільки високорозвинений інтелект, але й неабиякі здібності. Вони намагаються чітко передавати свої думки, бути красномовними і уважними, систематично поповнювати свій особистий тезаурус для того, щоб виділити себе серед інших однолітків[20].

Інтелектуальне самоствердження проявляється і у засвоєнні молодшими підлітками культури усного мовлення, за допомогою якої вони намагаються оволодіти правильною літературною мовою та технікою переказу. Культура усного мовлення являє собою володіння мовною технікою - сукупністю прийомів управління мовою. Ї̈̈ складові: міміка і пантоміміка; управління емоціями, настроєм; вдо- сконалення мовних даних (дикція, постановка голосу, темп і тембр мови).

Так, міміка і пантоміміка в процесі невербального спілкування молодших школярів підвищують емоційну значущість інформації, а тому оптимізують iï засвоєння. Процес сприйняття інформації залежить від тембру голосу, дикції суб'єкта, який передає інформацію. Багата звукова палітра голосу, чіткість промовляння слів, складів та звуків характерні для культурної особистості [14].

Тому інтелектуальне самоствердження в навчанні $є$ тією особливістю обумовлює формування інформаційної культури, оскільки молодшим підліткам притаманне прагнення до отримання нових знань, умінь та навичок.

Характерною особливістю молодшого підліткового віку виступає групова діяльність, яка найбільше задовольняє їх домінуючі потреби. В груповій діяльності вони намагаються засвоїти суспільну мораль, виробляють погляди, переконання, принципи і правила поведінки. У них формуються ідеали і цілі життя. Лише в контакті з іншими особистостями, зокрема з однолітками, молодший підліток бачить себе збоку, порівнює свої можливості, випробує різні соціальні ролі, і в решті-решт формує та удосконалює себе [27].

Отже, ще однією особливістю, що притаманна цьому вікові є схильність до групової діяльності, що сприяє процесу формування інформаційної культури, оскільки вона забезпечує здатність підлітків працювати в творчих групах.

Ми вважали за необхідне серед особливостей формування інформаційної культури молодших підлітків в загальноосвітньому навчальному закладі виділити таку особливість, як зародження світогляду у молодшого підлітка.

Дуже важливу роль для молодшого підлітка починає відігравати зміст інформації, який йому надається, його соціальна забарвленість та власне ставлення до нього. Вони починають оцінювати інформацію через призму певних поглядів, орієнтирів, установок, внутрішньо сприймають їі або відкидають. Цей «світоглядний» фільтр стає для них духовним світом [14].

Отже, особливість, як зародження світогляду у молодшого підлітка, сприяє формуванню інформаційної культури, тому що система знань молодших підлітків лише починає формуватися і педагоги можуть спрямувати їх відповідно до вимог інформаційної епохи. Це допоможе виховати таку особистість, яка готова не тільки існувати в епоху тонких інформаційних технологій, але і вести активну творчу діяльність.

Формуючи інформаційну культуру у молодших підлітків необхідно також звертати увагу на таку особливість, як становлення естетичних почуттів молодших підлітків. Для естетичного почуття є характерним те, що воно завжди пов'язане 3 духовним переживанням (задоволенням чи насолодою від краси) в процесі сприйняття багатогранних явищ дійсності і мистецтва. На основі розуміння і усвідомлення того, чому виникають різноманітні за характером 
переживання, молодшими підлітками набувається нова здатність - здатність до естетичної оцінки явищ дійсності, до опрацювання нової інформації. Саме ця здатність і $є$ естетичним смаком молодшого підлітка [13].

Отже, становлення естетичного почуття молодших підлітків, стає особливістю, що обумовлює формування інформаційної культури, тому що у спілкуванні з навколишнім світом у вихованців виникає прагнення до естетичних інформаційних потреб. Вони стають для них духовним стимулом до сприйняття нових предметів і явищ, які збагачують їх свідомість та досвід.

Інформаційна культура $є$ одним із найголовніших факторів формування гармонійно розвиненої особистості. Високий рівень інформаційної культури учнів $є$ передумовою двох найголовніших вмінь вміння адекватно формалізувати знання, які вони мають, і вміння адекватно їх інтерпретувати. Інформаційна культура включає у себе вміння підтримувати належну рівновагу між формалізованими та неформалізованими складовими знань людства. Саме таке почуття міри є одним із найголовніших чинників цілісності особистості і свідченням сформованості основ інформаційної культури [32].

Отже, нами було визначено особливості формування інформаційної культури молодших підлітків в умовах загальноосвітнього навчального закладу, а саме: отримання первинних навичок дослідницької діяльності, інтелектуальна активність, інтелектуальне самоствердження в навчанні, схильність до групової діяльності, схильність до експериментування, зародження світогляду у молодшого підлітка, становлення естетичних почуттів молодшого підлітка.

6. Результати дослідження та їх обговорення Врахування педагогом особливостей формування інформаційної культури молодших підлітків надає можливості домогтися ефективних результатів та позитивних змін в даному процесі.

Результати дослідження особливостей формування інформаційної культури молодших підлітків були використані у доповіді на науково-практичній конференції.

\section{7. Висновки та перспективи}

Отже, саме сьогодні інформаційна культура молодших підлітків постає як засіб захисту внутрішнього світу особистості, іiі індивідуальності в умовах багаторазового посиленого інформаційного впливу. Відповідно з цим і змінюються акценти розгляду процесу іiі формування. Інформаційну культуру у молодшому підлітковому віці не слід зводити тільки до комп'ютерної грамотності. Підхід до ії формування не може бути прийнятним тільки через вивчення інформатики, тому що він веде до звуження поняття «інформаційна культура». Формуючи інформаційну культуру, потрібно враховувати анатомо-фізіологічні, психологічні особливості молодшого підліткового віку, а також новоутворення притаманні цьому віку.

Визначення особливостей формування інформаційної культури молодших підлітків у навчально- виховному процесі загальноосвітнього навчального закладу актуалізувало необхідність розробки та впровадження нових педагогічних умов, змісту та методів його реалізації.

\section{Література}

1. Воробйов, Г. Г. Информационная культура в управленческом труде [Текст] / Г. Г. Воробйов. - М.: Экономика, 1971. - $106 \mathrm{c}$.

2. Антонова, С. Г. Информационное мировоззрение: К вопросу о сущности определения понятия [Текст] / С. Г. Антонова // Проблемы информационной культуры. 1996. - Вып. 3. - С. 23-28.

3. Зиновьева, Н. Б. Информационная культура личности [Текст]: учеб. пос. / Н. Б. Зиновьева. - Краснодар: КГАК, 1996. - $136 \mathrm{c}$.

4. Зубов, Ю. С. Информатизация и информационная культура [Текст]: сб. ст. / Ю. С. Зубов // Проблемы информационной культуры. - 1994. - С. 6-11.

5. Гендина, Н. И. Образование для общества знаний и проблемы формирование информационной культуры личности [Текст] / Н. И. Гендина // Научные и технические библиотеки. - 2007. - № 3. - С. 40-48.

6. Гречихин, А. А. Библиография и её мировоззренческая роль в информационной деятельности [Текст] / А. А. Гречихин // Проблемы информационной культуры. 1996. - Вып. 3. - С. 84-85.

7. Ершов, А. П. Информация: от компьютерной грамотности учащихся к информационной культуре [Текст] / А. П. Ершов // Коммунист. - 1982. - № 2. - С. 82-92.

8. Медведева, Е. А. Основи информационной культури [Текст] / Е. А. Медведева // Социс. - 1994. - № 11. - С. 59.

9. Семенюк, Е. П. Информационная культура общества и прогресс информатики [Текст] / Е. П. Семенюк. - К.: Наук.-техн. інформ. - 1994. - № 1. - С. 1-8.

10. Суханов, А. П. Информация и прогресс [Текст] / А. П. Суханов. - Новосибирск: Наука, 1998. - 192 с.

11. Хангельдиева, И. Г. О понятии «информационная культура»: тез. докл. междун. науч. конф. / И. Г. Хангельдиева // Информационная культура личности: прошлое, настоящее, будущее. - Краснодар, 1993. - С. 6.

12. Винарик, Л. С. Інформаційна культура в сучасному суспільстві [Текст] / Л. С. Винарик. - Донецьк: ДІЄХП, 2003. - 321 с.

13. Джинчарадзе, Н. Г. Інформаційна культура [Текст] / Н. Г. Джинчарадзе. - К.: Українські пропілеї, 1999. $-147 \mathrm{c}$.

14. Дулатова, А. Н. Информационная культура личности [Текст]: учеб. пособ. / А. Н. Дулатова, Н. Б. Зиновьева. - М.: Либерея-Бибинформ, 2007. - 176 с.

15. Коломієць, А. М. Інформаційна культура вчителя початкових класів [Текст] / А. М. Коломієць. - Вінниця: ВДПУ, 2007. - $379 \mathrm{c}$.

16. Матвієнко, О. В. Інформаційна культура особистості: освітньо-виховний контекст [Текст]: навч. метод. посіб. / О. В. Матвієнко. - К.: Ун-т економіки та права «КРОК», 2006. - $115 \mathrm{c}$.

17. Пруднікова, О. В. Інформаційна культура: концептуальні засади та світоглядний сенс [Текст] / О. В. Пруднікова. - Харків: Право, 2015. - 351 с.

18. Абрамова, Г. С. Возрастная психология [Текст]: учеб. пособ. / Г. С. Абрамова. - М.: Академ проект, 2001. $-704 \mathrm{c}$.

19. Блонский, П. П. О мышление подростка [Текст] / П. П. Блонский // Возрастная и педагогическая психология. 5-е изд., стереотип. - М.: Академия, 2008. - С. 273-275.

20. Савчин, М. В. Вікова психологія [Текст]: посіб. / М. В. Савчин, Л. П. Василенко. - К.: Академвидав, 2005. $360 \mathrm{c}$. 
21. Выготский, Л. С. Воображение и творчество подростка [Текст] / Л. С. Выготский // Возрастная и педагогическая психология. - 5-е изд., стереотип. - М.: Академия, 2008. - С. 283-285.

22. Забродський, М. М. Вікова психологія [Текст]: посіб. / М. М. Забродський. - К.: Академія, 2002. - 103 с.

23. Кле, М. Психология подростка [Текст] / М. Кле // Психология развития. - М.: ЧеРо, 2005. - С. 318-330.

24. Кутішенко, В. П. Вікова та педагогічна психологія (курс лекцій) [Текст]: навч. посіб. / В. П. Кутішенко. 2-ге вид. - К.: Центр учбової літератури, 2010. - 128 с.

25. Талько, М. І. Зміни в організмі молодшого підлітка [Текст] / М. І. Талько // Психолог. - 2006. № 2-3. - С. 36-37.

26. Терлецька, Л. Г. Дослідження особистісних рис підлітків [Текст] / Л. Г. Терлецька // Психолог. - 2003. № 34. - С. 16-24.

27. Фельдштейн, Д. И. Возрастная и педагогическая психология. Избранные психологические труды [Текст]: учеб. пособ. / Д. И. Фельдштейн. - Воронеж: Издательство НПО «МОДЭК», 2002. - $432 \mathrm{c}$.

28. Фруктова, Я. С. Формування морально-етичних норм у молодших підлітків [Текст] / Я. С. Фруктова // Психолог. -2006 . - № 33. - С. 7-10.

29. Андрощук, I. В. Організація і методика виховної роботи [Текст] / I. В. Андрощук. - Тернопіль: Богдан, 2014. -319 c.

30. Леонова, А. Б. Психодиагностика и регуляция функциональных состояний учашихся [Текст] / А. Б. Леонова; под ред. Г. Г. Аракелова // Учителям и родителям о психологии подростк. - М.: Высшая школа, 1990. C. $168-197$.

31. Онишків, 3. М. Основи школознавства [Текст] / 3. М. Онишків. - Тернопіль: Богдан, 2006. - 176 с.

32. Малишевський, О.В. Пропедевтика інформаційної культури учнів основної школи [Текст] / О. В. Малишевський. - Умань: Жовтий О. О., 2009. - 236 с.

33. Прихожан, А. М. Психологические проблемы подросткового возраста как пубертатного периода развития [Текст] / А. М. Прихожан // Возрастная и педагогическая психология. - 5-е изд., стереотип. - М.: Академия, 2008. C. $267-270$.

\section{References}

1. Vorobjov, G. G. (1971). Informacionnaja kul'tura v upravlencheskom trude [The information culture in administrative work]. Moscow: Jekonomika, 106.

2. Antonova, S. G. (1996). Informacionnoe mirovozzrenie: $\mathrm{K}$ voprosu o sushhnosti opredelenija ponjatija [The information world outlook: To the question about the essence of the definition of concept]. The problems of information culture, 3, 23-28.

3. Zinov'eva, N. B. (1996). Informacionnaja kul'tura lichnosti [The information culture of personality]. Krasnodar: KGAK, 136.

4. Zubov, Ju. S. (1994). Informatizacija i informacionnaja kul'tura [The informatization and information culture]. The problems of information culture, 6-11.

5. Gendina, N. I. (2007). Obrazovanie dlja obshhestva znanij i problemy formirovanie informacionnoj kul'tury lichnosti [The education for the knowledge society and the problems of formation of the information culture of personality]. The scientific and technical library, 3, 40-48.

6. Grechihin, A. A. (1996). Bibliografija i ejo mirovozzrencheskaja rol' v informacionnoj dejatel'nosti [The bibliography and its ideological role in information activities]. The problems of information culture, 3, 84-85.

7. Ershov, A. P. (1982). Informacija: ot komp'juternoj gramotnosti uchashhihsja $\mathrm{k}$ informacionnoj kul'ture [The in- formation: from computer literacy of pupils to the information culture]. Communist, 2, 82-92.

8. Medvedeva, E. A. (1994). Osnovi informacionnoj kul'turi [The foundations of information culture]. Socis., 11, 59.

9. Semenjuk, E. P. (1994). Informacionnaja kul'tura obshestva i progress informatiki [The information culture of society and progres of informatics]. Kyiv: The scientific and technical information, 1, 1-8.

10. Suhanov, A. P. (1998). Informacija i progress [The information and progres]. Novosibirsk: Nauka, 192.

11. Hangel'dieva, I. G. (1993). About the concept of «information culture». The information culture of personality: Past, Present, Future. Krasnodar, 6.

12. Vynaryk, L. S. (2003). Informatsiina kultura v suchasnomu suspilstvi [The information culture in modern society]. Doneck: DIIeKhP, 321.

13. Dzhyncharadze, N. H. (1999). Informatsiina kultura [The information culture]. Kyiv: Ukrainski propilei, 147.

14. Dulatova, A. N., Zinov'eva, N. B. (2007). Informacionnaja kul'tura lichnosti [The information culture of personality]. Moscow: Libereja-Bibinform, 176.

15. Kolomiiets, A. M. (2007). Informatsiina kultura vchytelia pochatkovykh klasiv [The information culture of teacher of primary classes]. Vinnitsa: VDPU, 379.

16. Matviienko, O. V. (2006). Informatsiina kultura osobystosti: osvitno-vykhovnyi kontekst [The information culture of personality: educational context]. Kyiv: Un-t ekonomiky ta prava «KROK», 115.

17. Prudnikova, O. V. (2015). Informatsiina kultura: kontseptualni zasady ta svitohliadnyi sens [The information culture: conceptual foundations and ideological sense]. Kharkiv: Pravo, 351.

18. Abramova, G. S. (2001). Vozrastnaja psihologija [The age-related psychology]. Moscow: Akadem proekt, 704.

19. Blonskyi, P. P. (2008). About the thinking of teenager. The age-related and pedagogical psychology. Moscow: Akademiya, 273-275.

20. Savchyn, M. V., Vasylenko, L. P. (2005). Vikova psykholohiia [The age-related psychology]. Kyiv: Akademvydav, 360.

21. Vygotskiy, L. S. (2008). The imagination and creation of a teen-ager. The age-related and pedagogical psychology. Moscow: Akademiya, 283-285.

22. Zabrodskyi, M. M. (2002). Vikova psykholohiia [The age-related psychology]. Kyiv: Akademiia, 103.

23. Kle, M. (2005). The psychology of a teen-ager. The psychology of development. Moscow: CheRo, 318-330.

24. Kutishenko, V. P. (2010). Vikova ta pedahohichna psykholohiia (kurs lektsii) [The age-related and pedagogical psychology (lectures)]. Kyiv: Tsentr uchbovoi literatury, 128.

25. Talko, M. I. (2006). Zminy v orhanizmi molodshoho pidlitka [The changes in the organism of the young teenager]. Psychologist, 2-3, 36-37.

26. Terletska, L. H. (2003). Doslidzhennia osobystisnykh rys pidlitkiv [The research of personality traits of teenagers]. Psychologist, 34, 16-24.

27. Fel'dshtejn, D. I. (2002). Vozrastnaja i pedagogicheskaja psihologija. Izbrannye psihologicheskie trudy [The age-related and pedagogical psychology. The selected psychological work]. Voronez: Izdatel'stvo NPO «MODJeK», 432.

28. Fruktova, Ia. S. (2006). Formuvannia moralnoetychnykh norm u molodshykh pidlitkiv [The formation of moralethical norms in the young teen-agers]. Psychologist, 33, 7-10.

29. Androshchuk, I. V. (2014). Orhanizatsiia i metodyka vykhovnoi roboty [The organization and methods of educational work]. Ternopol: Bohdan, 319.

30. Leonova, A. B.; Arakelov, G. G. (Ed.) (1990). Psihodiagnostika i reguljacija funkcional'nyh sostojanij uchashihsja [The psychodiagnostics and regulation of functional states 
of pupils]. For teachers and parents about the psychology of teen-agers. Moscow, 168-197.

31. Onyshkiv, Z. M. (2006). Osnovy shkoloznavstva [The foundations of school science]. Ternopol: Bohdan, 176.

32. Malyshevskyi, O. V. (2009). Propedevtyka informatsiinoi kultury uchniv osnovnoi shkoly [The propedevtika information culture of secondary school pupils]. Uman': Zhovtyi O. O., 236.

33. Prihozhan, A. M. (2008). The psychological problems of adolescence age as the pubertal period of development. The age-related and pedagogical psychology. Moscow: Akademiya, 267-270.

Дата надходження рукопису 12.04.2016

Тріфаніна Любов Сергіївна, аспірант, кафедра соціальної педагогіки, Національний педагогічний університет імені М. П. Драгоманова, вул. Пирогова, 9, м. Київ, Україна, 01601

E-mail:LubaS17@mail.ru

Вайнола Рената Хейкіївна, доктор педагогічних наук, професор, кафедра соціальної педагогіки, Національний педагогічний університет імені М. П. Драгоманова, вул. Пирогова, 9, м. Київ, Україна, 01601

E-mail:Vainola@ukr.net

\title{
УДК 37(477)(092)
}

\section{ІСТОРІОГРАФІЯ І ДЖЕРЕЛЬНА БАЗА ДОСЛІДЖЕННЯ ПЕДАГОГІЧНОЇ СПАДЩИНИ В. Д. СИПОВСЬКОГО (1844-1895 РР.)}

\author{
(C) Д. М. Хрипун
}

У статті на основі архівних, маловідомих та опублікованих джерел здійснено системний $і$ комплексний аналіз педагогічної спадщини В. Д. Сиповського (1844-1895 рр.). Висвітлено основні питання, які стосуються аналізу джерельної бази й історико-педагогічної літератури з досліджуваної теми. Подальшого розвитку набули аналіз і систематизація досліджень з даної проблеми

Ключові слова: джерельна база, історіографія, В. Д. Сиповський, Колегія Павла Галагана, Петербурзьке училище глухонімих

In the article was relized the system and complex analysis of pedagogical heritage of V. D. Sypovsky (18441895) based on the archival, little-known and published sources. The four stages of the study of this problem were separated:

1) intravital historiography;

2) historiography of pre-soviet period;

3) historiography of soviet period;

4) modern Ukrainian and Russian historiography.

The maim questions of the analysis of the source base and historical-pedagogical literature on the studied topic were elucidated. The analysis and systematization of the studies on the given problems gained the further development. Into the scientific usage were introduced the little-known and unknown documents that widened the historical-pedagogical knowledge about the life activity of the famous teacher, educator, historian, linguist, specialist in literature, editor and publisher on the base of memories, necrologues and the other documents devoted to the personality of $V$. Sypovsky. Historiographic analysis of the literature on the problem of research at every stage of the development of historical-pedagogical science gave an opportunity to state the topicality and singnificance of the personality of $V$. Sypovsky in the socio-cultural conditions of that time

Keywords: source base, historiography, V.D. Sypovsky, Collegue of Pavlo Galagan, St. Petersburg specialized school for the deaf-mutes

\section{1. Вступ}

На сучасному етапі модернізації середньої освіти в Україні актуалізуються звертання науковців до педагогічної спадщини видатних педагогів. Особливий інтерес педагогів та істориків викликає період другої половини XIX - початку XX століття. Педагогічна спадщина видатних вчителів та вихователів другої половини XIX - початку XX століття є змістовним джерелом, аналіз та осмислення глибин якого, безумовно, сприятиме удосконаленню української системи освіти як важливої складової виховання та навчання молодого покоління. У цьому контексті великого значення набуває історіографічне дослідження педагогічної спадщини Василя Дмитровича Сиповського.

2. Історіографія і джерелльна база дослідження педагогічної спадщини В. Д. Сиповського (1844-1895 рр.).

Перший етап - до першої половини 90-х років XIX ст. - праці, що вийшли до юбілейних дат заснування навчальних закладів де працював видатний педагог, серед них: „Двадцатипятилетие С.-Петербургской седьмой гимназии (бывшей Вто- 